\title{
A historic event: The first female officer of the American Association for Thoracic Surgery
}

\author{
Jennifer S. Lawton, MD
}

\section{ABSTRACT}

At the 10oth meeting of the AATS, the first woman ever was nominated to be an officer. Dr Yolonda Colson was nominated as Vice President and will be the first female President of the AATS. We celebrate her amazing and inspiring accomplishments. (J Thorac Cardiovasc Surg 2021;161:730-2)

Cardiothoracic surgeons around the world rejoiced today when Dr Yolonda Colson (Figure 1) was nominated as the Vice President of the American Association for Thoracic Surgery (AATS). No woman has ever served as an officer of the AATS. During this 100th meeting, sadly held virtually because of the Coronavirus Disease 2019 pandemic, we celebrate a historic event!

From the Division of Cardiac Surgery, Department of Surgery, Johns Hopkins University, Baltimore, Md.

Received for publication May 24, 2020; revisions received June 3, 2020; accepted for publication June 3, 2020; available ahead of print July 5, 2020.

Address for reprints: Jennifer S. Lawton, MD, Johns Hopkins Hospital, 1800 Orleans

St Zayed 7107, Baltimore, MD 21287 (E-mail: jlawton4@jhmi.edu).

$0022-5223 / \$ 36.00$

Copyright (c) 2020 by The American Association for Thoracic Surgery

https://doi.org/10.1016/j.jtcvs.2020.06.079

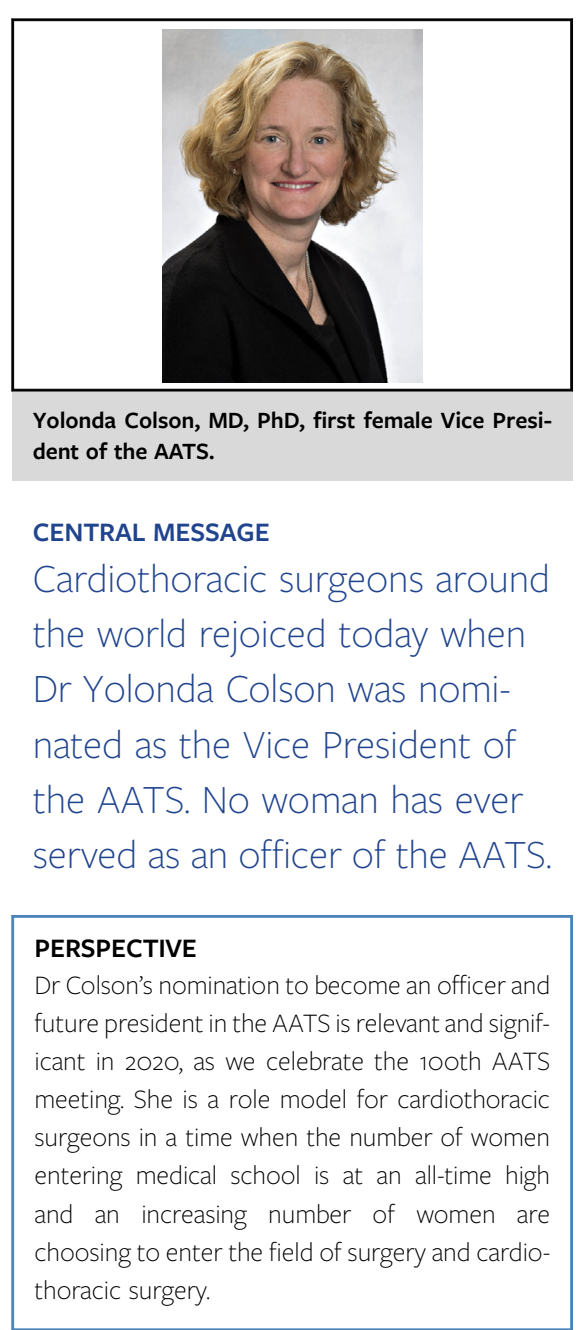

Dr Colson is one of the rare female cardiothoracic surgeons who is a full professor, funded by the National Institutes of Health, and a chief of her division. She is the Chief of Thoracic Surgery at Massachusetts General Hospital. Dr Colson is the Hermes C. Grillo Professor of Surgery, Harvard Medical School, Massachusetts General Hospital. Before this position, she was the inaugural Michael A. Bell Family Distinguished Chair in Healthcare Innovation, the Executive Director for Surgical Innovation, and the Vice Chair of Surgical Innovation of the Department of Surgery, Brigham and Women's Hospital. She obtained a Bachelor of Science in Biomedical Engineering from Rensselaer Polytechnic Institute, Doctor of Medicine from the Mayo Medical School, and a Doctor of Philosophy from the University of Pittsburgh. She did her General Surgery training 


\section{Abbreviations and Acronyms \\ AATS $=$ American Association for Thoracic Surgery \\ $\mathrm{NIH}=$ National Institutes of Health}

at the University of Pittsburgh and Cardiothoracic Surgery fellowship at Brigham and Women's Hospital. She was the co-chair of the 2015 AATS Annual Meeting Program and currently is the Chair of the Advisory Committee for the AATS Foundation. She is the Examination Chair for the American Board of Thoracic Surgery and has received the Edward M. Kennedy Award for Health Care Innovation from the Center for Integration of Medicine and Innovative Technology at Massachusetts General Hospital. She holds 3 patents and has received more than 20 foundation grants and 7 RO1 grants from the National Institutes of Health $(\mathrm{NIH})$ and National Cancer Institute. She currently holds 4 RO1 grants from the NIH and has contributed more than 140 peer-reviewed publications to the literature.

It was only 3 years ago, in 2017 in Boston, that the AATS celebrated its Centennial and 100 years of the AATS. When

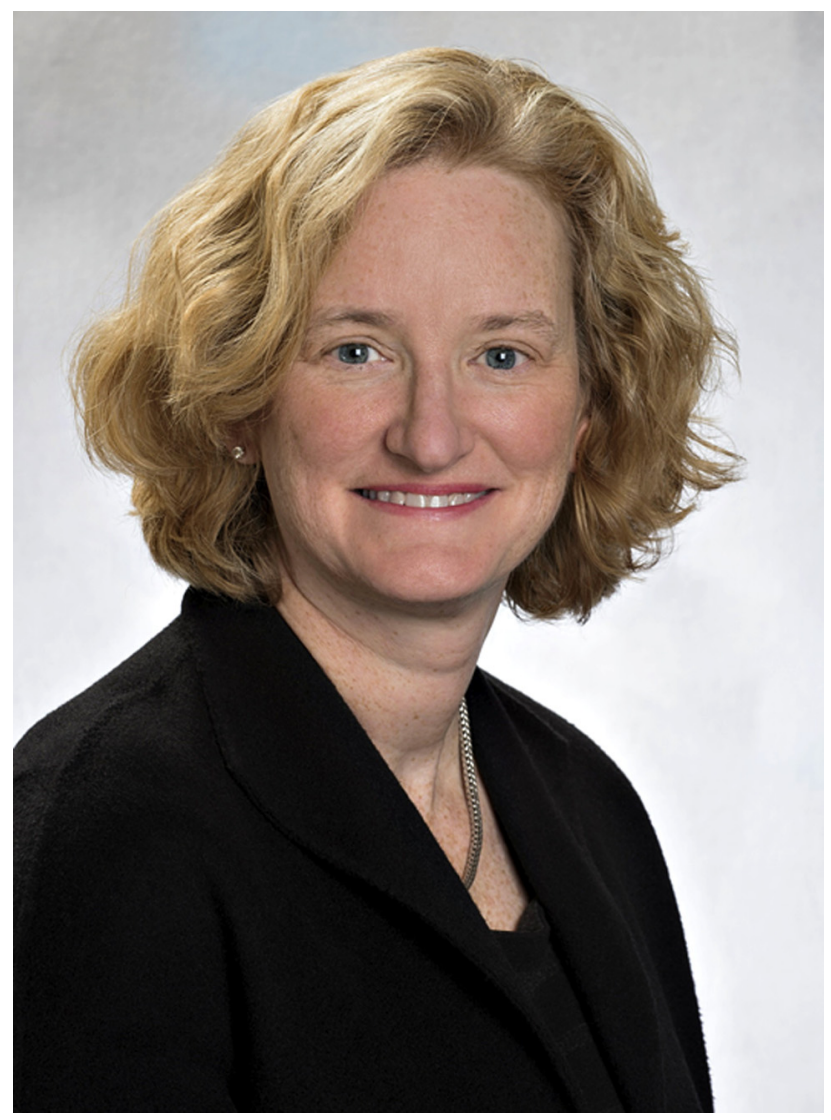

FIGURE 1. Yolonda Colson, MD, PhD. attendees of the meeting entered the meeting, they marveled at the photographs of the past 100 presidents along the walls. Many were surprised and wondered why they were all men (99 white and 1 Latin American).

To put Dr Colson's accomplishments into perspective, the AATS is an organization with a fixed membership (900) with only 65 female members (with a 30\% increase in female members with the 2019 new membership class) (Figure 2). This includes the first woman, Nina Starr Braunwald, who became a member in 1967. Interestingly, the next female member was not until 1988. Only 4 women have served on the leadership body (Board of Directors, formerly the Council) of the AATS. Only 3 female members of the AATS have served as a chair of a committee. Two women currently serve on the AATS Foundation Board of Directors.

Although women make up greater than $50 \%$ of medical school graduates, and increasing numbers of surgical residents $(40 \%)$ and cardiothoracic surgery fellows $(20 \%)$, women have constituted a minority of leaders in surgical societies. ${ }^{1-3}$ Women comprise a minority of cardiothoracic surgeons, $8.4 \%$ (6.2\% adult cardiac, $10.6 \%$ congenital, and $12.6 \%$ general thoracic), according to the recent Society of Thoracic Surgeons Practice and Access Task Force Report, ${ }^{4}$ and women similarly represent a minority of cardiothoracic surgeons at top-ranked US institutions ( $7.3 \%$ overall, $5.1 \%$ cardiac, and $12.7 \%$ of thoracic). ${ }^{5}$ In 2011 , only the 200th woman earned board certification by the American Board of Thoracic Surgery, 62 years after the first board examination in 1949., ${ }^{3,6}$ Although they remain in the minority, women have served as chairs or executive directors of American Specialty Boards of Surgery, including the American Board of Thoracic Surgery and American Board of Surgery. ${ }^{7}$ Women have been elected to serve as president of many professional societies, including the Society of Thoracic Surgeons (Dr Carolyn Reed was elected posthumously), Southern Thoracic Surgical Association, Western Thoracic Surgical Association, American Surgical Association, American College of Surgeons, Association for Academic Surgery, Society of Vascular Surgery, Society of University of Surgeons, American College of Cardiology, and many others.

Fewer female medical school faculty have obtained the rank of full professor compared with men, ${ }^{7,8}$ and in 2016, only 3 female $(6 \%)$ cardiothoracic surgeons were at the rank of full professor, compared with $237(40 \%)$ male cardiothoracic surgeons. ${ }^{5}$ At that time, only 2 women $(3.9 \%)$ who were practicing cardiothoracic surgeons were chairpersons of their department/division compared with 122 men $(19.2 \%))^{7}$ Likewise, fewer women have received Research Project Grants funded by the NIH since 2000 compared with men, ${ }^{9}$ fewer practicing cardiothoracic female surgeons have received any NIH funding compared with men, ${ }^{5}$ and only 4 practicing female cardiac surgeons 


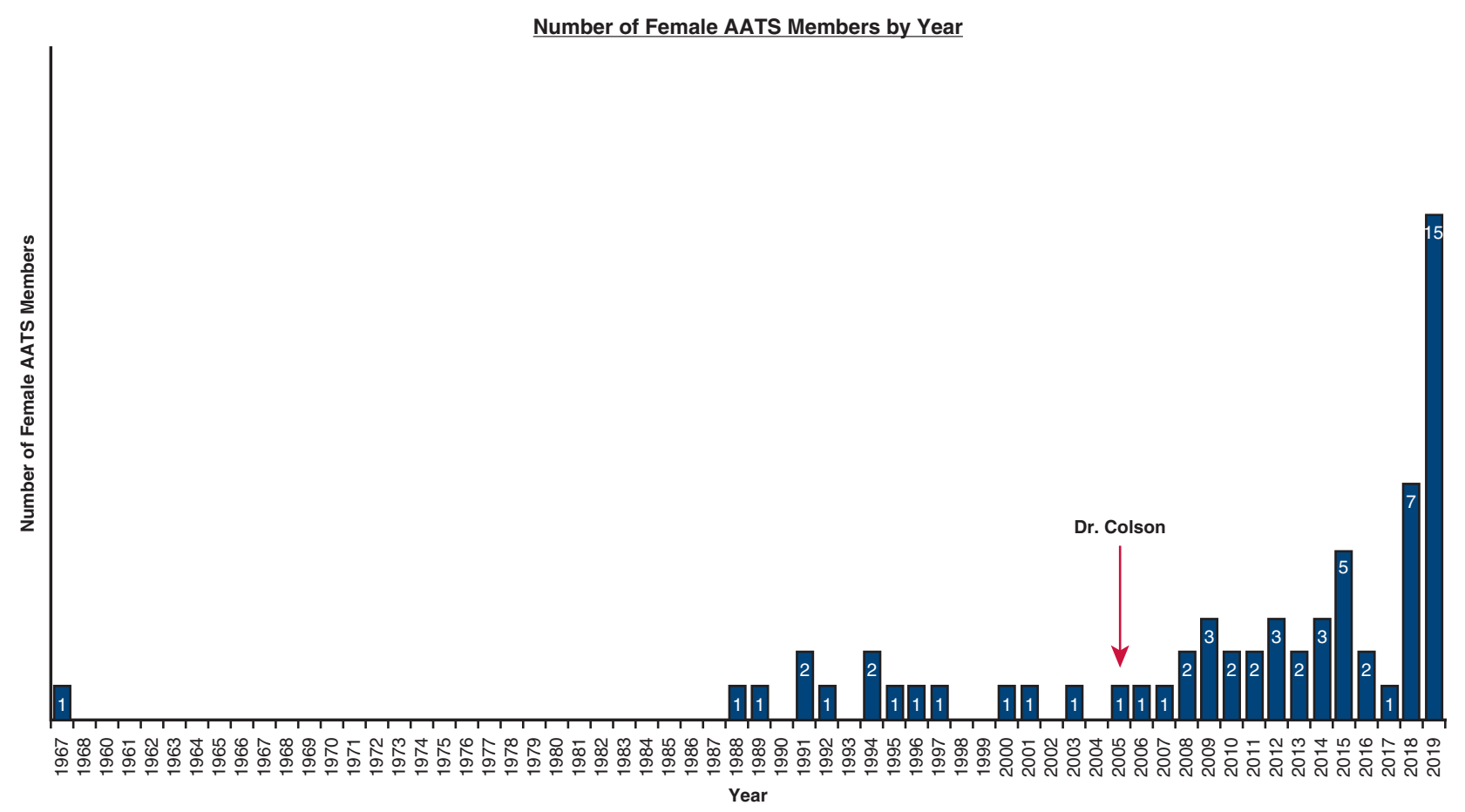

FIGURE 2. Female AATS Members. The graph depicts the number of new AATS members by year starting with the first female AATS member in 1967.

have ever been funded by the $\mathrm{NIH},{ }^{10}$ representing $2.8 \%$ of all NIH-funded cardiac surgeons.

Dr Colson is an outstanding leader, mentor, and surgeon. She manifests all of the values of the AATS: leadership, education, research and innovation, excellence in patient care, and mentoring. She is a superstar, and now she will be the first woman to serve as an officer and future president in the AATS. Dr Colson's perspectives, views, and experiences will enlighten the trajectory of the AATS and provide a spark for the evolution of our specialty. We raise our glass to toast and congratulate Dr Colson and eagerly await her presidency in the AATS! We also congratulate the AATS leadership for this selection. Evidence from the corporate world confirms that organizations that prioritize inclusivity and diversity are more successful, and the AATS will similarly benefit from Dr Colson's presence, as well as from diversity of all minority, racial, and ethnic groups. Dr Colson is blazing a trail for many more women to come.

\section{Conflict of Interest Statement}

The author reported no conflicts of interest.

The Journal policy requires editors and reviewers to disclose conflicts of interest and to decline handling or reviewing manuscripts for which they may have a conflict of interest. The editors and reviewers of this article have no conflicts of interest.

\section{References}

1. Jagsi R, Means O, Lautenberger D, Jones RD, Griffith KA, Flotte TR, et al. Women's representation among members and leaders of national medical specialty societies. Acad Med. October 15, 2019 [Epub ahead of print].

2. Aziz HA, DuCoin C, Welsh DJ, Paramo JC, Andreone P, Butsch DW, et al. 2018 ACS Governors Survey: Gender Inequality and Harassment Remains a Challenge in Surgery. American College of Surgeons Bulletin; 2019:21-30.

3. Stephens EH, Robich MP, Walters DM, DeNino WF, Aftab M, Tchantchaleishvili V, et al. Gender and cardiothoracic surgery training: specialty interests, satisfaction, and career pathways. Ann Thorac Surg. 2016;102:200-6.

4. Ikonomidis JS, Boden N, Atluri P. The Society of Thoracic Surgeons thoracic surgery practice and access task force -2019 workforce Report. Ann Thorac Surg. 2020:S0003-4975(20)30561-0.

5. Rosati CM, Koniaris LG, Molena D, Blitzer D, Su KW, Tahboub M, et al. Characteristics of cardiothoracic surgeons practicing at the top-ranked US institutions. J Thorac Dis. 2016;8:3232-44.

6. Baumgartner B. American Board of Thoracic Surgery Spring Meeting ABTS, Past and Present. American Board of Thoracic Surgery. Available at: https://www.abts.org/ABTS/About/About\%20ABTS/ABTS/Public/About/ History.aspx ?hkey $=\mathrm{e} 552012 \mathrm{f}-770 \mathrm{~b}-4 \mathrm{e} 0 \mathrm{~d}-8 \mathrm{~d} 5 \mathrm{f}-6 \mathrm{cabc524a845}$. Accessed June 2, 2020.

7. Pories SE, Turner PL, Greenburg CC, Babu MA, Parangi S. Leadership in American surgery women are rising to the top. Ann Surg. 2019;269:199-205.

8. Carr PL, Raj A, Kaplan SE, Terrin N, Breeze JL, Freund KM. Gender differences in academic medicine: retention, rank, and leadership comparisons from the National Faculty Survey. Acad Med. 2018;93:1694-9.

9. NIH Physician-Scientists Workforce (PSW) Report 2014. Available at: https:// report.nih.gov/Workforce/PSW/med_degree.aspx. Accessed May 22, 2020.

10. Narahari AK, Cook IO, Mehaffey JH, Chandrabhatla AS, Hawkins RB, Tyerman Z, et al. Comprehensive National Institutes of Health funding analysis of academic cardiac surgeons. J Thorac Cardiovasc Surg. 2020;159:2326-35.e3.

Key Words: leadership, scholarship, innovation, education, gender, sex 